\title{
Selenium Status in Heifers, Late Pregnancy Cows and Their Calves in the Šumava Region, Czech Republic
}

\author{
P. SLAVÍK ${ }^{1}$, J. ILLEK ${ }^{2}$, T. ZELENÝ 3 \\ ${ }^{1}$ Department of Animal Nutrition, ${ }^{2}$ Clinic of Ruminant Diseases, \\ University of Veterinary and Pharmaceutical Sciences, Brno, Czech Republic \\ ${ }^{3}$ Veterinary Centre, Sušice, Czech Republic
}

Received February 7, 2006

Accepted November 15, 2007

\begin{abstract}
Slavík P., J. Illek, T. Zelený: Selenium Status in Heifers, Late Pregnancy Cows and Their Calves in the Sumava Region, Czech Republic. Acta Vet Brno 2007, 76: 519-524.

The objective of this study was to ascertain selenium status in beef cattle in different stages of production in the Šmava region. In the region, blood collections and analyses for selected metabolic variables were performed in 54 animals in different production stages (18 heifers, 18 cows in late pregnancy and 18 calves aged 3 weeks on the average). Three herds were studied. The selenium status was determined both directly by measuring serum selenium (Se) contents and indirectly by measuring glutathione peroxidase (GSH-Px) activity in whole blood. The mean serum selenium concentration in all the animals under study $(\mathrm{n}=54)$ was $30.6 \mu \mathrm{g} / 1+/-2.91$, and mean GSH-Px activity was 167.01 $\mu \mathrm{kat} / 1+/-92.39$. In heifers, mean serum selenium concentration was $34.81 \mu \mathrm{g} / 1+/-13.84$; mean GSHPx activity was $186.96 \mu \mathrm{kat} / 1+/-112.15$. In late pregnancy cows, mean serum selenium concentration was $26.58 \mu \mathrm{g} / 1+/-8.01$, mean GSH-Px activity was $94.55+/-35.72 \mu \mathrm{kat} / \mathrm{l}$. In calves, mean serum selenium concentration and GSH-Px activity were $30.41 \mu \mathrm{g} / \mathrm{l}+/-12$ and $219.54 \mu \mathrm{kat} / 1+/-64.41$, respectively. There was a statistically significant difference between the heifers and late pregnancy cows in both variables under study. However, between the late pregnancy cows and the calves, only the difference in GSH-Px activity was significant. The results indicate severe Se deficiency in the animals under study. It means apart from other things that mineral licks used did not provide enough minerals to meet the basic requirements of the animals.
\end{abstract}

Cattle, calves, selenium, beef cattle, glutathione peroxidase

Based on the socioeconomic changes that have led to fundamental agricultural reforms, extensive beef cattle rearing systems have started to develop in marginal agricultural regions as one of the ways of environmentally friendly landscape management. Although this type of production is not in the forefront of scientific interest, there are many serious problems of a factor nature, mainly in calf rearing. This study focused on the problems related to selenium. The objective of this study was to ascertain the selenium status in cattle of different production stages in the region under observation.

First reports on the occurrence of selenium deficiency in this region and its impact on the health status were published more than 30 years ago (Kursa 1969).

Selenium performs many functions in the body. These include an effect on the development and motility of sperm, influence on immunity indicators (improvement of bactericidal activity of neutrophile granulocytes, increase in antibody production), effect on fertility (fewer cases of retained placenta) (Underwood and Suttle 1999).

Selenium is a natural antioxidant. It protects organellae and cell membranes containing lipids from oxidation by reactive oxygen species (ROS). ROS include for instance superoxide anion, hydroxyl radical, perhydroxyl radical, hydrogen peroxide and singlet oxygen (Baldi 2005). Functional forms of selenium are selenoproteins. The most important selenoproteins are glutathione peroxidase (GSH-Px), thioredoxine reductase (TR), iodthyronine-5deiodinase, selenoprotein P and tens of others (Underwood and Suttle 1999).

Address for correspondence:

MVDr. Petr Slavík, Ph.D.

Czech University of Life Science Prague

Department of Veterinary Sciences

Kamýcká 129

CZ 16521 Prague - Czech Republic
Phone: +420 224382948

Cell: +420 607727743

E-mail: slavik.pe@seznam.cz

http://www.vfu.cz/acta-vet/actavet.htm 
Many researchers have demonstrated a positive correlation between selenium concentrations and GSH-Px activity in the blood.

In cattle, the correlation was demonstrated by Pavlata et al. (2001) for example, who determined a correlation coefficient of 0.93 , using 44 heads of cattle, and Pavlata et al. (2000) who received a correlation coefficient of $r=0.90$ with 326 animals. The results of their studies imply that the determination of selenium status based on GSH-Px activity measurement can be used in herds where all the animals receive equal diets.

Because selenium is incorporated in erythrocytes in the form of selenocysteine only during erythropoesis, GSH-Px activity becomes an indicator of long-term selenium status in the body. On the contrary, Se concentrations in whole blood reflect a momentary selenium status (Harapin et al. 2000; Enjalbert et al. 1999).

Selenium passes the placental barrier and is important for the intrauterine development of calves. Obviously, this Se function is very important, because even if the cow is moderately Se deficient, the calf receives a sufficient Se supply. However, this is at the expense of increasing Se deficiency in the cow. However, when the cow suffers from severe Se deficiency, the calf is affected, too. The Se deficiency in the calf will become more severe in the course of time because Se levels in the colostrum and milk are correlated with the selenium status of the cow (Enjalbert et al. 1999; Gunter et al. 2003). This, however, was not demonstrated by Pavlata et al. (2003), who monitored the correlation between the selenium status of the cow and selenium levels in her colostrum. However, only a few animals were included in the study.

In the body of a pregnant female, mainly in the last third of pregnancy, the uterus is given priority to other organs in the distribution of some substances, according to the homeorhesis principle (VanSaum et al. 1989).

The basic selenium level in beef cattle diets, recommended by NRC (National Research Council) is $0.3 \mathrm{mg}$ Se per kg dry matter (NRC 2001).

Stowe and Herdt (1992) considered 70 - $100 \mu \mathrm{g} / \mathrm{l}$ as normal, and $40-70 \mu \mathrm{g} / \mathrm{l}$ as marginal levels. Nevertheless, they pointed out that production performance must be taken into account when evaluating Se levels. According to Gerloff (1992), Se levels under $40 \mu \mathrm{g} / \mathrm{l}$ indicate Se deficiency in cattle. Pavlata et al. (2000) reported slightly different values (see below).

The objective of this study was to clarify the situation concerning supplying of selenium in extensive raising of beef cattle in a region where this system of agricultural prodution is very widespread.

\section{Materials and Methods}

Animals included in this study were chosen from 3 beef cattle herds in the Šumava region. In total, 36 or 54 animals in three different production stages were included. The average altitude of the farms was $450 \mathrm{~m}$.

Herd 1: Piemontaise breed (20 animals in the herd), Herd 2: Simmental (45 animals), Herd 3: Hereford (86 animals).

In the spring of 2004, before the start of the grazing season the herds were subjected to performance checks, and veterinary treatments were performed. Blood samples were taken as a part of the veterinary control.

In each herd, two groups of animals were randomly selected, each including 6 animals. The first group included non-pregnant young heifers only. The second group included late pregnancy cows that were due very soon. Calves born to these cows were blood-sampled at an average age of three weeks. All the calves ingested colostrum spontaneously in the first hours of life. None of them were administered a selenium-vitamin supplement parenterally between birth and blood collection.

The animal health status was examined, too. However, we did not observe marked or significant mass occurrence of signs typical of mineral deficiencies.

Animals in all the herds had free access to the mineral lick BIOXANON ${ }^{\circledR}$, the composition of which is given in Table 1. In all the herds, the feeding of the vitamin premix VITAMIX S8 (BIOFAKTORY) was continued. The premix composition is given in Table 2 . Its intake was irregular, and the mean daily intake was less than $20 \mathrm{~g}$ per head (the manufacturer recommends $50-150 \mathrm{~g}$ per head per day), as calculated from the total consumption in a given period.

In the summer, animals graze in the pasture, and in the winter they are fed hay and grass silage that is produced in the region. In the winter, in herd 3, corn silage is fed occasionally. Samples of the winter diet were collected, i.e., of hay and grass silage for each herd, and the average selenium contents were determined. 
Table 1. Composition of mineral lick - BIOXANON ${ }^{\circledR}$

\begin{tabular}{|l|c|l|}
\hline Mineral & Content in $1 \mathrm{~kg}$ & \multicolumn{1}{|c|}{ Form } \\
\hline Sodium $(\mathrm{Na})$ & $350 \mathrm{~g}$ & Sodium chloride \\
\hline Calcium $(\mathrm{Ca})$ & $17 \mathrm{~g}$ & \multirow{2}{*}{ Hydrogen calcium phosphate monohydrate } \\
\hline Phosphorus $(\mathrm{P})$ & $12 \mathrm{~g}$ & Magnesium(II) oxide \\
\hline Magnesium $(\mathrm{Mg})$ & $3 \mathrm{~g}$ & Zinc(II) oxide \\
\hline Zinc $(\mathrm{Zn})$ & $4 \mathrm{~g}$ & Iron(II) sulphate monohydrate \\
\hline Iron $(\mathrm{Fe})$ & $3.5 \mathrm{~g}$ & Manganese(II) oxide \\
\hline Manganese $(\mathrm{Mn})$ & $3.5 \mathrm{~g}$ & Anhydrous calcium iodate \\
\hline Iodine $(\mathrm{I})$ & $120 \mathrm{mg}$ & Sodium selenite \\
\hline Selenium $(\mathrm{Se})$ & $20 \mathrm{mg}$ & Cobalt(II) sulphate heptahydrate \\
\hline Cobalt $(\mathrm{Co})$ & $10 \mathrm{mg}$ & \\
\hline
\end{tabular}

Table 2. Composition of the vitamin supplement VITAMIX S8®

\begin{tabular}{|l|c|l|}
\hline Mineral & Content in $1 \mathrm{~kg}$ & \multicolumn{1}{|c|}{ Form } \\
\hline Sodium $(\mathrm{Na})$ & $95 \mathrm{~g}$ & Sodium chloride \\
\hline Calcium $(\mathrm{Ca})$ & $180 \mathrm{~g}$ & Sodium carbonate \\
\hline Phosphorus (P) & $30 \mathrm{~g}$ & Hydrogen calcium phosphate monohydrate \\
\hline Magnesium $(\mathrm{Mg})$ & $70 \mathrm{~g}$ & Magnesium(II) oxide \\
\hline Zinc $(\mathrm{Zn})$ & $6 \mathrm{~g}$ & Zinc(II) oxide \\
\hline Copper $(\mathrm{Cu})$ & $1 \mathrm{~g}$ & Copper(II) sulphate pentahydrate \\
\hline Manganese (Mn) & $5 \mathrm{~g}$ & Manganese(II) oxide \\
\hline Iodine (I) & $110 \mathrm{mg}$ & Calcium iodate \\
\hline Selenium $(\mathrm{Se})$ & $30 \mathrm{mg}$ & Sodium selenite \\
\hline Cobalt $(\mathrm{Co})$ & $20 \mathrm{mg}$ & Hydroxide cobalt(II) carbonate \\
\hline Vitamin $\mathrm{A}$ & 900 thousand i.u. & \\
\hline Vitamin $\mathrm{D}_{3}$ & 110 thousand i.u. & \\
\hline Vitamin $\mathrm{E}$ & $1100 \mathrm{mg}$ & Alpha-tocopherol \\
\hline & &
\end{tabular}

All the blood collections for one herd were performed at one time. Blood was withdrawn from the coccygeal and jugular veins, using the $\operatorname{HEMOS}^{\circledR}$ system, both to obtain serum and, using heparin, to determine GSH-Px activity.

After the GSH-Px determination, the heparinised whole blood samples were placed in a thermal box, and then in a refrigerator when we returned to the laboratory. The blood samples intended for serum selenium determination were allowed to coagulate at room temperature. The samples were processed in the laboratory on the next day after each collection. The laboratory analyses were made, using the COBAS MIRA analyser. Selenium levels were measured by the atomic absorption spectrophotometer (AAS) using the hydride method. The activity of glutathione peroxidase (GSH-Px) in the erythrocytes was measured using the method described by Paglia and Valentine (1967) and the RANDOX-RANSEL RS 505 kit was used.

Selenium concentration in the serum was determined by hydride generation and atomic absorption spectrophotometry (HG-AAS) as described by Sturman (1985). Mineralization was performed in a microwave oven.

For GSH-Px activity and selenium evaluation, the following reference values were used (Pavlata et al. 2000): $<70 \mu \mathrm{g} / \mathrm{l}$, or $<472 \mu \mathrm{kat} / 1$ - deficiency from 70 to $100 \mu \mathrm{g} / \mathrm{l}$ or from 472 to $665 \mu \mathrm{kat} / 1$ - marginal status $100 \mu \mathrm{g} / 1 \mathrm{or}$ $<665 \mu \mathrm{kat} / 1$ - adequate status.

Data were processed using Microsoft Excel. Mean value (x) and standard deviation (S.D.) were calculated, and $t$-test was performed to compare groups of late pregnancy cows and their calves $(P<0.05)$.

\section{Results and Discussion}

The mean selenium concentration in all $(\mathrm{n}=54)$ animals under study was $30.6 \mu \mathrm{g} / \mathrm{l}+/-$ 2.91 in blood serum and mean GSH-Px activity was $167.01 \mu \mathrm{kat} / 1+/-92.39$ in whole blood. The mean values of Se concentration in GSH-Px activity in different animal categories are given in Table 3. 
Table 3. Mean plasma Se concentrations and GSH-Px activities in the animals under study. (x - mean, S.D. - standard deviation of the mean, $P$ - $t$-test)

\begin{tabular}{|l|c|c|c|c|c|c|}
\hline & \multicolumn{2}{|c|}{ Heifers $(\mathrm{n}=18)$} & Cows in late pregnancy $(\mathrm{n}=18)$ & \multicolumn{2}{c|}{ Calves $(\mathrm{n}=18)$} \\
\hline & $\mathrm{Se}$ & GSH-Px & $\mathrm{Se}$ & GSH-Px & Se & GSH-Px \\
\hline & $\mu \mathrm{g} / 1$ & $\mu \mathrm{kat} / 1$ & $\mu \mathrm{g} / \mathrm{l}$ & $\mu \mathrm{kat} / 1$ & $\mu \mathrm{g} / 1$ & $\mu \mathrm{kat} / 1$ \\
\hline $\mathrm{x}$ & 34.81 & 186.96 & 26.58 & 94.55 & 30.41 & 219.54 \\
\hline S.D. & 13.84 & 112.15 & 8.01 & 35.72 & 12 & 64.41 \\
\hline Max. & 69.81 & 509 & 43.74 & 182.3 & 59.12 & 303.4 \\
\hline Min. & 19.13 & 82.21 & 13.49 & 48.3 & 11.06 & 15.3 \\
\hline$P^{\mathrm{a}}$ & & & $*$ & $* *$ & & \\
\hline$P^{\mathrm{b}}$ & & & & & & $* *$ \\
\hline
\end{tabular}

$P<0.05$

$* * P<0.01$

$P^{a} t$-test between the groups of heifers and the cows in late pregnancy

$P^{\mathrm{b}} t$-test between the groups of the cows in late pregnancy and their calves

The results show that the selenium status in the animals under study was poor. Three herds were monitored and in none of them did mean Se contents and GSH-Px activities achieve marginal values. Only in herd 3, some of the individual measured values approached the marginal status level. However, in neither herd the marginal levels were exceeded.

In feed samples collected in herd 1, mean dietary selenium content was $0.1 \mathrm{mg} / \mathrm{kg}$ dry matter (DM), in herd 2, mean Se content was $0.093 \mathrm{mg} / \mathrm{kg} \mathrm{DM}$, and in herd 3, mean Se content was $0.088 \mathrm{mg} / \mathrm{kg} \mathrm{DM}$.

In the Sumava region, beef cattle is mostly grazed, with emphasis placed on extensive rearing with minimum costs. Except for mineral licks and sporadic provision of mineral feed, animals receive no mineral supplements. Our results clearly show that the Se contained in hay and grass in the pasture cannot meet their requirements.

Nevertheless, Stowe and Herdt (1992) and Gerloff (1992) reported that it is important to take into account the milk yield, which is much lower in beef cattle. On the other hand, beef cows have higher requirements for muscle growth. Specific Se levels for beef cattle in the serum, tissues and other body fluids have not been determined. However, the mean values obtained indicate severe deficiency as compared with Gerloff (1992). Only in herd 3 , did individual values in some animals exceed the Se serum content of $40 \mu \mathrm{g} / \mathrm{l}$.

In accordance with data reported (Enjalbert et al. 1999; Gunter et al. 2003), highest concentrations were found in heifers, i.e. non-pregnant animals. Significantly lower values were received from the $t$-test analysing differences in Se concentrations $(P<0.05)$ and GSH-Px activities $(P<0.01)$ between heifers and late pregnancy cows. We did not manage to find significant differences in Se concentrations between late pregnancy cows and their calves, although absolute values in calves were higher than those in their mothers. There was a significant difference in GSH-Px activity $(P<0.01)$ between the groups.

Pavlata et al. (2003) demonstrated a correlation between Se serum concentrations in pregnant cows and their calves. This is in accordance with the results obtained by Illek et al. (2002), who reported higher Se concentrations in calves than in their mothers. However, in all the groups under study, selenium deficiency at the time of calving was only moderate or marginal. However, the above studies did not analyse whether selenium contents in the newborn calves were really significantly higher than in severely Se-deficient mothers. The results of the present study indicate that the homeorhesis principle cannot be confirmed when the mother is severly Se-deficient. High GSH-Px values in calves do not correspond to the correlation coefficients determined by Pavlata et al. (2000, 2001). In both studies, GSH-Px was analysed in whole blood. Thus, it was GSH-Px that is present in cytosol of erythrocytes. For more detailed elucidation of the 
contradiction between the studies, it would be useful to know the haematocrit values and other haematological indicators, both in cows and their calves. It is known that newborn calves show higher haematocrit values. Foetal erythropoiesis that differs a little from that of a newborn can play a role, too. Some researchers expressed the activity of GSH-Px in E.U./kg, i.e. enzyme units per gram of haemoglobin, defined as enzyme activity level required for oxidation of $1 \mu \mathrm{mol}$ NADPH per minute at $21^{\circ} \mathrm{C}$ (Rowntree et al. 2004), taking into account the amount of haemoglobin and thereby erythrocyte counts, which is not considered if the enzyme activity is expressed in $\mu$ kat per 1 .

Rowntree et al. (2004) found some irregularities in GSH-Px concentration. They ascribed them to the effects of breed or environment. Awadeh et al. (1998) also reported discrepancies in GSH-Px activity and Se concentration, however, in their opinion these were due to the irregular intake of Se from a lick. This fact could have played a certain role in heifers and late pregnancy cows in this study. The results suggest that the use of GSH-Px as an indirect measure of selenium status in the production stages of cattle investigated is somewhat disputable.

The severe selenium deficiency ascertained is not surprising because the dietary selenium level recommended by NRC (2001) is $0.3 \mathrm{mg} / \mathrm{kg}$ DM and the values we measured were lower than onethird of the recommended level. Such levels (including Se supplemented by mineral licks) cannot cover even the marginal requirements of the animal. The difference between the required and toxic levels, however, is very small.

It can be stated that when cows are raised extensively on pasture and their diet is not regularly supplemented with concentrated feeds in which a mineral premix could be added, they suffer from selenium deficiency. A mineral lick with increased selenium contents is not sufficient to help achieve an adequate selenium status.

\section{Zásobení selenem u jalovic, vysokobřezích krav masných plemen a jejich telat v regionu Šumava v ČR}

Cílem studie bylo zjistit stav zásobení selenem různých kategorií zvířat u masného skotu v regionu Šumava. V tomto regionu byly provedeny odběry a stanovení vybraných parametrů metabolizmu u 54 zvířat různých věkových kategorií (18 jalovic, 18 vysokobřezích krav a 18 telat v průměrném věku 3 týdny). Sledování bylo provedeno ve třech chovech. Stav zásobení selenem byl stanoven na základě přímého stanovení selenu (Se) v krevním séru a též nepřímo pomocí měření aktivity glutathionperoxidázy (GSH-Px) v plné krvi. Průměrná koncentrace selenu u všech $(\mathrm{n}=54)$ sledovaných zvíŕat činila 30,6 $\mu \mathrm{g} / 1$ +/- 2,91 a průměrná aktivita GSH-Px 167,01 $\mu \mathrm{kat} / 1$ +/- 92,39. Průměrná hodnota koncentrace selenu u jalovic byl 34,81 $\mu \mathrm{g} / 1+/-13,84$ a aktivity GSH-Px 186,96 $\mu \mathrm{kat} / 1+/-112,15$ u vysokobřezích krav 26,58 $\mu \mathrm{g} / 1+/-8,01$ při aktivitě GSH-Px 94,55 +/- 35,72 $\mu \mathrm{kat} / \mathrm{l}$ a u telat 30,41 $\mu \mathrm{g} / 1+/-12$ při aktivitě 219,54 $\mu \mathrm{kat} /$ $1+/-64,41$. Statisticky významný rozdíl byl mezi skupinou jalovic a vysokobřezích krav, ale mezi skupinami vysokobřezích krav a telat se podařilo prokázat statisticky významný rozdíl pouze v aktivitě GSH-Px. Výsledky ukazují na hlubokou deficienci tohoto mikroprvku u sledovaných kategorií zvíră. Mimo jiné to znamená, že minerální liz není schopen pokrýt ani základní potřebu zvířete. Dủsledky tohoto stavu na zdravotní stav a ekonomiku chovu budou předmětem dalších studií.

\section{Acknowledgement}

The study was supported by the Ministry of Agriculture of the Czech Republic (grant No. QF 4005)

\section{References}

AWADEH FT, ABDELRAHMAN MM, KINCAID RL, FINLEY JW 1998: Effect of selenium supplements on the distribution of selenium among serum proteins in cattle. J Dairy Sci 81: 1089-1094

BALDI A 2005: Vitamin E in dairy cows. Livest Prod Sci 98: 117-122 
ENJALBERT F, LEBRETON P, SALAT O, SCHELCHER F 1999: Effects of pre- or postpartum selenium supplementation on selenium status in beef cows and their calves. J Anim Sci 77: 223-229

GERLOFF BJ 1992: Effect of selenium supplementation on dairy cattle. J Anim Sci 77: 223-229

GUNTER SA, BECK PA, PHILLIPS JM 2003: Effects of supplementary selenium source on the performance and blood measurements in beef cows and their calves. J Anim Sci 81: 856-864

HARAPIN I, BAUER M, BEDRICA L, POTOCNJAK D 2000: Correlation between glutathione peroxidase activity and the quantity of selenium in the whole blood of beef calves. Acta Vet Brno 69: 87-92

ILLEK J, PAVLATA L, LOKAJOVÁ E, BEČVÁŘ O, MATĚJÍČEK M 2002: Effect of Selenium Supplementation to Gravid Heifers on Selenium Concentration and Glutathion peroxidase Activity in Blood of Newborn Calves. Proceeding XXII. World Buiatrics Congress Hannover - Abstracts 18 - 23 August 2002, 74 p.

KURSA J 1969: Nutriční svalová degenerace u mladého skotu v distriktu Šumavy. Vet Med (Praha) 14: $549-559$

NRC 2001: Nutrient Requirements of Domestic Animals, Nutrient Requirements of Cattle. $7^{\text {th }}$ ed.. National Academy of Sciences, Washington, DC, $263 \mathrm{p}$.

PAGLIA DE, VALENTINE WN 1967: Studies on the quantitative and qualitative characterization of erythrocyte glutathione peroxidase. J Lab Clin Med 70:158-169

PAVLATA L, PECHOVÁ A, ILLEK J 2000: Direct and indirect assessment of selenium status in cattle: a comparison. Acta Vet Brno 69: 281-287

PAVLATA L, PECHOVÁ A, BEČVÁŘ O, ILLEK J 2001: Selenium status in cattle at slaughter: analyses of blood, skeletal muscle, and liver. Acta Vet Brno 70: 277-284

PAVLATA L, PRÁŠEK J, PODHORSKÝ A, PECHOVÁ A, HALOUN T 2003: Selenium metabolism in cattle: maternal transfer of selenium to newborn calves at different selenium concentrations in dams. Acta Vet Brno 72: 639-646

ROWNTREE JE, HILL GM, HAWKINS DR, LINK JE, RINCKER JM, BEDNAR GW, KREFT RA 2004: Effect of Se on selenoprotein activity and thyroid hormone metabolism in beef and dairy cows and calves. J Anim Sci 82: 2995-3005

STOWE HD, HERDT TH 1992: Clinical assessment of selenium status of livestock. J Anim Sci 70: 3928-3933

STURMAN BT 1985:Development of a continuous-flow hydride and mercury vapour generation accessory for atomic absorption spectrophotometry. Appl Spectrosc 39: 48-56

UNDERWOOD EJ, SUTTLE NF 1999: The Trace Elements. In: The Mineral Nutrition of Livesteck $3^{\text {rd }}$. CABI Publishing Oxon, UK, pp. 125-138

VAN SAUM RJ, HERDT TH, STOWE HD 1989: Maternal and fetal selenium in neonatal calves. J Dairy Sci 67: $1128-1137$ 